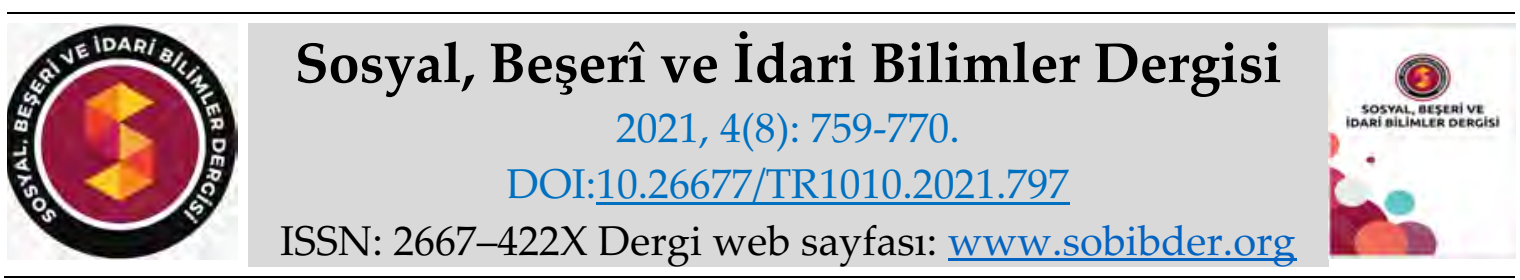

KAVRAMSAL MAKALE

\title{
Gesamtkuntwerk Kavramına Göre Müzik ve Resim İlişkisi
}

Dr. Öğr. Üyesi Emre ŞEN, Çankırı Karatekin Üniversitesi, Güzel Sanatlar Enstitüsü, Çankırı, eposta: sen emre@msn.com

ORCID: https://orcid.org/0000-0001-5016-6461

Şeyma ÇÖLGEÇEN, Yüksek Lisans Öğrencisi, Çankırı Karatekin Üniversitesi, Güzel Sanatlar Enstitüsü, Çankırı, e-posta: symcolgecen@gmail.com

ORCID: https://orcid.org/0000-0003-1699-4188

Öz

Avusturyalı ressam Gustav Klimt Art Nouveau'nun kurucularındandır. Gustav Klimt'in ürettiği birçok eserde desenler, heykeller, mitolojik karakterler, kadın portreleri bulunmaktadır. Gustav Klimt ise kendi sanatı hakkında şu sözleri söylemiştir:

"Kendim veya sanatım hakkında bir şey söylemem gerektiğinde, ben ne yazılı ne de sözlü söz söyleme yeteneğine sahibim. Benim sanatçı kişiliğime dair kim bir şey öğrenmek istiyorsa, kayda

değer yapılacak tek şey resimlerime dikkatlice bakmak ve benim ne olduğumu ve ne yapmak istediğimi görmeye çalı̧̧maktır."

Avusturyalı Ayrılık ustası Klimt, en çok dekoratif tablolarıyla tanınmaktadır. 1902'de büyük müzisyen Beethoven'in onuruna yarattığı Beethoven Frizi içerik bakımından zengindir. Besteci Beethoven'ın 9 numaralı Senfoni ile bağlantısı ve kendi mitolojik unsurlarının yorumlanması da dahil olmak üzere bu eser Gesamtkunstwerk kavramına önemli bir örnek teşkil etmektedir. Aralarında kültürler arası bir sanat izomorfizmi vardır. Yirminci yüzyılın şafağındaki yaratıcı uyanışın önemli bir eseri olan Beethoven Frizi, insanın mutluluk özlemiyle hareket eden üç duvar boyunca yayılan bir anlatıyı gözler önüne sermektedir. Resim, heykel ve müzik gibi farklı sanatların ortak bir tema altında birleştirildiği Gesamtkunstwerk 'in muhteşem bir gerçekleştirmesidir. Bu makalenin amacı; Gesamtkunstwerk kavramını (bütünlüklü sanat eseri, ideal sanat eseri) resim estetiği üzerinde ele almaktır.

Anahtar Kelimeler: Beethoven, Gesamtkunstwerk, Klimt, 9.Senfoni, Beethoven Frizi.

Makale Gönderme Tarihi: 07.05.2021

Makale Kabul Tarihi: 01.08.2021

\section{Önerilen Atıf:}

Şen, E. ve Çölgeçen, Ş. (2021). Gesamtkuntwerk Kavramına Göre Müzik ve Resim İlişkisi, Sosyal, Beşeri ve İdari Bilimler Dergisi, 4(8): 759-770.

(c) 2021 Sosyal, Beşerî ve İdari Bilimler Dergisi. 


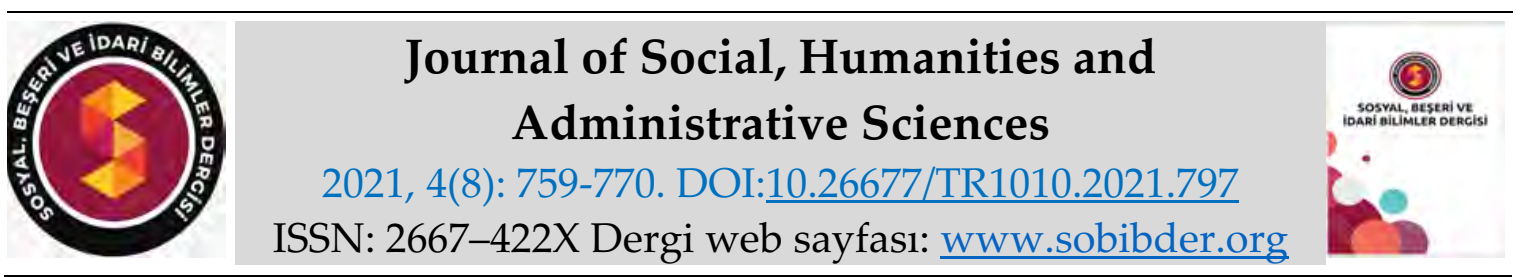

CONCEPTUAL PAPER

\title{
The Relationship of Music and Painting According to The Concept of Gesamtkuntwerk
}

Assistant Prof. Dr Emre ŞEN, Çankırı Karatekin University, Fine Arts Institute, Çankırı, e-mail: sen emre@msn.com

ORCID: https://orcid.org/0000-0001-5016-6461

Şeyma ÇÖLGEÇEN, MSc. Student, Çankırı Karatekin University, Fine Arts Institute, Çankırı, email: symcolgecen@gmail.com

ORCID: https://orcid.org/0000-0003-1699-4188

\begin{abstract}
Austrian painter Gustav Klimt is one of the founders of Art Nouveau. Many works by Gustav Klimt include patterns, sculptures, mythological characters, and female portraits. Gustav Klimt said the following about his art:

"When I need to say something about myself or about my art, I am neither able to speak in writing nor verbally. Whoever wants to learn about my artistic personality, the only thing worthwhile is to look carefully at my paintings and try to see what I am and what I want to do."

Austrian Separation master Klimt is best known for his decorative paintings. The Beethoven Frieze, created in 1902 in honor of the great musician Beethoven, is rich in content. This work, including the composer Beethoven's connection with Symphony No. 9 and his interpretation of his own mythological elements, is an important example of the concept of Gesamtkunstwerk. There is an art isomorphism between cultures. The Beethoven Frieze, an important work of the creative awakening at the dawn of the twentieth century, reveals a narrative that spans three walls moving with human longing for happiness. It is a magnificent realization of Gesamtkunstwerk, where different arts such as painting, sculpture and music are combined under a common theme. The purpose of this article is; To discuss the concept of Gesamtkunstwerk (complete work of art, ideal work of art) on the aesthetics of painting.
\end{abstract}

Keywords: Beethoven, Gesamtkunstwerk, Klimt, 9th Symphony, Beethoven Frieze.

Received: 07.05.2021

Accepted: 01.08.2021

\section{Suggested Citation:}

Şen, E. and Çölgeçen, Ş. (2021). The Relationship of Music and Painting According to The Concept of Gesamtkuntwerk, Journal of Social, Humanities and Administrative Sciences, 4(8): 759-770.

(c) 2021 Sosyal, Beşerî ve İdari Bilimler Dergisi. 


\section{Gíriş}

Gesamtkunstwerk kavramından söz edebilmek, her şeyden önce resim ve sanat ilişkisinde konumlanan estetik kavramını daha detaylı düşünmekle mümkün olabilir. Çünkü kavramın barındırdığ1 estetik kaygılar, sözcügüun etimolojik kökeninde gözlenebilir. Estetik sözcügüu, Yunanca Aisthancsthai (duymak, algllamak), aisthesis (duygu, duyum) sözcüklerinden gelmektedir. Alman filozof Baumgarten'in 1750'de yayımladığı Aesthetica adlı yapıtında, bu sözcüğü kullanması ile başlayan bir "estetik" geleneği varlığından söz edilebilir (De Bolla, 2006; Doğan, 1975).

19. yüzyılın ortalarından itibaren estetik kavramının 'güzel' olan anlamı ağırlık kazandığından, sözcügün sanatla sürekli ve güçlü bir bağ1 olmuştur (Williams, 2007). Estetik teriminin düşünce tarihinde değerli olmasının yanında bir felsefe kolu olarak Alman düşünür Kant ile önem kazanmıştı. Kant'a göre "estetik us, kuramsal us ile uygulayıcı us arasında bir köprüdür ve kuramın uygulama alanındaki denetçisidir" (Hançerlioğlu, 2008: 93). Estetik idealleri ile sinema, müzik, resim, heykel, tiyatro, opera gibi birçok sanat dalında kullanılmış olan Gesamtkunstwerk kavramı ise, türlü yönleriyle sanat kuramlarında oldukça geniş yer edinmiştir.

\section{GESAMTKUNSTWERK KAVRAMININ DÜŞÜNDÜRDÜKLERİ}

Gesamtkunstwerk; 'bütünsel sanat', 'bütüncül eser', 'birleşik sanat eseri', 'toplu sanat eseri', 'bütün yapit', 'topyekûn sanat deneyimi' anlamlarına gelen Almanca menşeli bir kavramdır (Millington, 1992; Tanju, 2010; Haydaroğlu, 2011). Türk Dil Kurumu Almanca-Türkçe Sözlügü̈'ne göre Gesamtkunstwerk kavramı şöyle tanımlanır (Önen ve Şanbey, 1993: 409): "Değişik sanatsal etkinliklerin bir sanat eserinde (örn. Operada) gösterilmesi. 'Sözen ve Tanyeli'ye göre (1986: 90) ise kavramın tanımı şöyledir: aynı üslup ve sanatsal anlayışla gerçekleştirilmiş resim, heykel, bezeme, mobilya ve diğer uygulamalı sanat ürünlerinin, tek bir eser bünyesinde bütünleşip, bir araya gelişidir.

Gesamtkunstwerk terimi, ilk olarak Alman yazar ve filozof K.EE. Trahndorff'un 1827 tarihli yazısında ve Wagner'in 1849 tarihli çalışmasında kullanılmıştır (Wagner 1993). Daha sonra özellikle Wagner'in estetik idealleriyle özdeşleştirilerek Wagner'e mal edilmiştir (Millington, 1992). Kavram, operada önemli nitelikte gelişmelere sahne olan; sinemayı, tiyatroyu, sanatın tüm dallarını kapsayan bir kuram olarak değerlendirilebilir. Bu kuram sahnelenen, gösterilen veya kâğıda dökülen her şeyin aynı düzlemde estetize edilme isteğiyle mükemmelliği amaçlayan 'tamamlanmış' sanat eserine ulaşmayı savunmaktadır.

19. yüzyıl, sanat formlarının doğuşuna tanıklık eden bir dönemdi ve Gesamtkunstwerk fikri 1840'larda ortaya konduğunda, tüm sanatların arakesiti olarak düşünülmüştü. Öncelikli olarak Wagner'in tanımladığı, sonraları farklı bağlamlarda yorumlanmış Gesamtkunstwerk kavramı; 1900 yıllarında Viyana'daki sanat ortamı, 1919-1933 yılları arasında Bauhaus'un yarattığı etkiler dikkate alındığında çeşitli çağrışımları gündeme getirmiştir (Sönmez, 2011:22). Yaratıcı sanatların bir araladığına ve yakınlığına işaret eden kavram, 1960'lı yıllardan sonra daha farklı bir kapsamda ele alınmaya başlanmıştır; yani disiplinler arası olmaktan çok bir 'tavır ve model' rolüne bürünmüştür (Sönmez, 2011:25).

Gesamtkunstwerk sadece türlü tekniklerin, medyanın, akademik disiplinlerin bir sentezi olarak değil; aynı zamanda izleyici ile kurulan diyalogta bir anlam olarak sanatın kavramsallaştırılma hâline de işaret etmektedir (Frampton, 2007.90; Galard, 2011:27). Lebbeus Woods'un (2010) bir 'fikir' olarak tanımladığı Gesamtkunstwerk, tüm 19. yüzyıl Romantik ideallerin mevcut olması anlamına gelmektedir. Bu bağlamda Wagner operayı bir Gesamtkunstwerk olarak anlatırken; Sedlmayr (1998), operanın performatif hâlinin Gotik katedraldeki sahneleme ile benzer olduğunu 
dile getirir çünkü Wagner yanılsama, gösteriş, korolar, sesler kullanarak ve algı unsurlarını kapatmaya uğraşan bir görkem yaratarak izleyiciyi etkilemeye çalışır (Tanju, 2010). Modern çağın başında, yeni sanat formları ve sanatların yeni biçimlerini bulmaya ihtiyaç görülmemişken; birçok antik medeniyette ve Orta Çağ katedrallerinde, Rönesans sarayları ve Barok kiliselerinde mimarlık, resim, heykel gibi sanatlar bir arada kullanılmıştır (Woods 2010). Bunun yanında Modernistler, Bauhaus ekolü ve Rus konstrüktivistleri de aynı birlikteliği sağlamak için çabalamışlardır.

2000'li yılların ardından ise Gesamtkunstwerk kavramı; sınırların eridiği, birlikteliklerin ön plana çıtığı bir kavrayış tarzına bürünmüştür (Sönmez, 2011:24). Hem çok şey söyleyen hem de hiçbir şey söylemeyen kavram hem yaşayan hem de ölü olan tavra işaret eden bir zombiye benzetilebilir (Durmuş, 2009). Günümüzde "topyekûn sanat tecrübesi' gibi bir tarife doğru evirilen kavram; çeşitli dallara uzanan sanat pratiğinin temsilciliğini yapmayı sürdüren isimlerin de sanat eserlerine yönelik düşüncelerini yönlendirmiştir (Altuğ, 2011:70).

"Sanatlar, sistemler değil, organizmalardır: sanat eseri çă̆̆n organik bir parçasıdır ve her çă̆ kendi özgülformlarına sahiptir. Çă̆lar arasındaki değişiklik, yalnızca temsil biçimlerinin değiş̧ikliği değildir (Masiero, 2006: 170). "

\section{Gesamtkunstwerk ve Müzik Estetiği Üzerine}

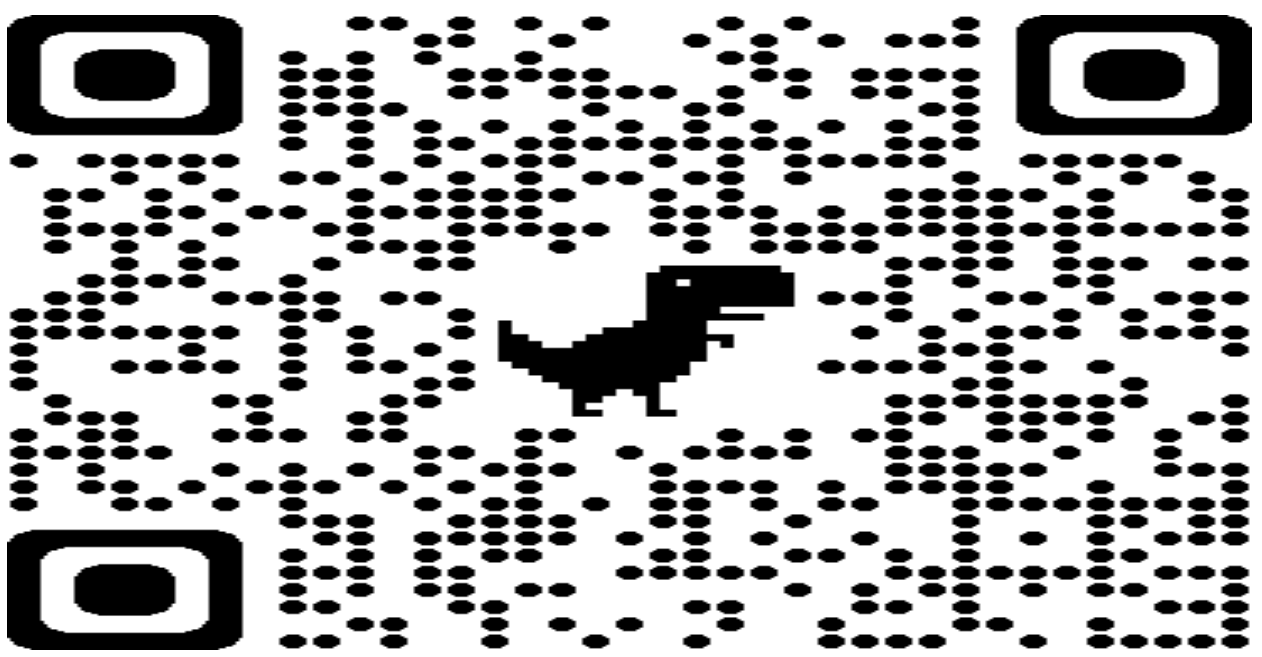

(DecimusAquila, 2008). ${ }^{1}$

Gesamtkunstwerk kavramının yukarıda belirtilen tanımları ve zaman içerisindeki gelişimi, sanat ve estetik arasındaki ilişkinin gözlenmesinde de önemlidir. Goethe'nin Faust kitabına ilgisi bilinen Klimt, 'Beethoven Frizi' adlı eseriyle birlikte besteci Gustav Mahler tarafından yazılmış ve uyarlanmış bir orkestraya yer verir (Galard, 2011:26). Klimt 'Beethoven Frizi' eseriyle birlikte heykel, resim ve müziği birlikte işleyerek adeta Goethe'nin işaret ettiği Gesamtkunstwerk kavramının bedenleşmiş hâlini yansıtmıştır. Müzik estetiği ve sanat ilişkisi söz konusu olduğunda ise Wagner, şu satırları sarf etmiştir (Most, 2011: 5):

\footnotetext{
${ }^{1}$ Telefonunuzun kamerasını açıp barkodu okutarak Beethoven'nın 9.Senfonisine ulaşabilirsiniz.
} 
"İşte şimdi bütün uygar dünyayı dolduran hâliyle sanat! Onun gerçek doğası sanayi, ahlaksal amacı para, estetik bahanesi de sıkılanların oyalanması. "

Fubini (2006) Wagner'in vurgusunu özellikle ifade gücüne ve duyguları verme kapasitesine yaptığına İşaret eder. Wagner Gesamtkunstwerk kavramını ortaya koyarak beste kaygısını kuramlaştırmayı denerken bu kaygıyı tiyatro ve müziği bir arada düşünerek opera çerçevesinde yorumlamıştır. Böylelikle müzik ve tiyatro türü olarak operanın evrimi üstüne yeni bir kuramsal çatkı oluşturmayı denemiştir (Most, 2011:8).

\section{Frizin "Çifte" Yorumu}

Genel olarak tarihin ve kültürün dış çevresi tarafından desteklenebilecek bir sanat eserini açıklıyoruz ya da yapıtın içerdiği unsurları analiz ederek doğrudan anlayabiliriz. Bu sanat eseri Klimt tarafından yaratıldığından beri, çeşitli yorumcular onun esrarengiz insan vücudu imajını yorumlamaya çalıştılar. Beethoven sergisinin kataloğu, anlamının birincil ipucu olarak 1902 sergisinde serginin kataloğu, Viyanalı Ayrılıkçı ressamın eseri ile onun altında yatan felsefesi arasındaki bağlantıyı açıç̧a gösteriyor.

Serginin ana teması, Beethoven'in müzik ruhuna uygun olarak, zayıf insanlığın sanat ve aşk aracılığıyla kurtuluşunu somutlaştırıyor. Alman besteci Beethoven sadece Viyana klasik müziğinin temsilcisi değil, aynı zamanda Batı romantik müziğinin de öncülerindendir. Üstün müzik dehası, asi ruhu, güçlü kararlılığı ve yüksek sosyal sorumluluğu onu özel niteliklere sahip bir müzisyen yaptı. Senfonide, derin felsefeyi dokunaklı sanatsal imgelerle birleştiren, mücadeleden zafere, karanlıktan aydınlığa, sefaletten mutluluğa ruhsal süreci gösteren tema olarak zamanı ve bireysel kaderi aldı. Klimt 'in Beethoven frizi ile Senfoni No. 9 arasında gerekli bir bağlantı vardır çünkü Klimt doğrudan Beethoven'in Dokuzuncu Senfonisinin son korosuna atıfta bulunmuştur (Vergo, 1973:110)

Serginin kataloğundan, birinci odadaki üç duvarın üst katını kaplayan frizin, Viyanalılardan Beethoven'in çok renkli heykeli orta odada duran Alman meslektaşı Max Klinger 'e bir 'saygi' parçası olduğu söylenmektedir. Gösterinin odak noktası olarak. Üç boyalı duvar uyumlu bir sıra oluşturur.

$\mathrm{Bu}$ sıralar aynı zamanda ahşap taşıyıcıların kenarlarında orijinal sıraya karşılık gelmeyecek şekilde numaralandırılır (Vergo, 1973:110).

Başka bir deyişle, sanat eseri, kişinin kendisininkine göre yapay olarak birkaç bölüme ayrılabilir. Yorumlama, düşündügünüz gibi üç veya dört bölüm gibi. Odanın genel düzenlemesine göre Beethoven Frizi üç bölüme ayrılabilir (Görsel 1).

Sol duvarın teması "Mutluluk özlemi"dir. Heykelin arkasındaki ön duvar, tema "Düşman Kuvvetler" sağ duvardaki tema ise "Mutluluk arzusu şiir ve aşkta doyum bulur" şeklindedir (Vergo, 1973:110).

Geçmişte, geleneksel resim üç boyutlu biçim duygusunu ışık, gölge ve karanlık taraf üzerinden modellemiştir ve nesnenin gerçek temsilini vurgulamıştır. Bu sanat eserinin yaratılışı geleneksel resimlerle keskin bir tezat oluşturan grafik, çizgi ve dekoratif çizim dili ile yapılmıştır. Afrika kolonilerinden getirilen ilkel maskelerin, kapların ve diğer el sanatlarının etkisi, ayrılık sanatçlarına "ilkel" süslemeyi, düz çizgileri ve doğal dekorasyonu taklit etmeleri için ilham vermiştir (Vergo, 1973:110). Ortadaki yoğun renk blokları haricinde, görüntülerin geri kalan ekranın sonunda çok fazla beyaz boşlukla işlenmiştir. Renk parçalarının dizilişinin ve çizgilerin şiddetinin sanatçının duyguları ile ilişkili olduğu apaçık görülebilmektedir. Yaratıcı duyguların 
güçlü ve zayıf yönleri de müzikteki trendlerle uyumluydu. Beethoven'in duygularının senfonide güçlenen ya da zayıflayan duygularını takip edebileceğiniz gibi, aynı resim için de geçerli, açık, yumuşak ve basitten karanlığa, güçlü ve karmaşığa doğru hareket etmektedir. Beethoven Frizindeki olay örgüsü ve atmosfere göre, 9 numaralı Senfoni'nin dört hareketiyle bir dereceye kadar tutarlı olabilir (Görsel 2).

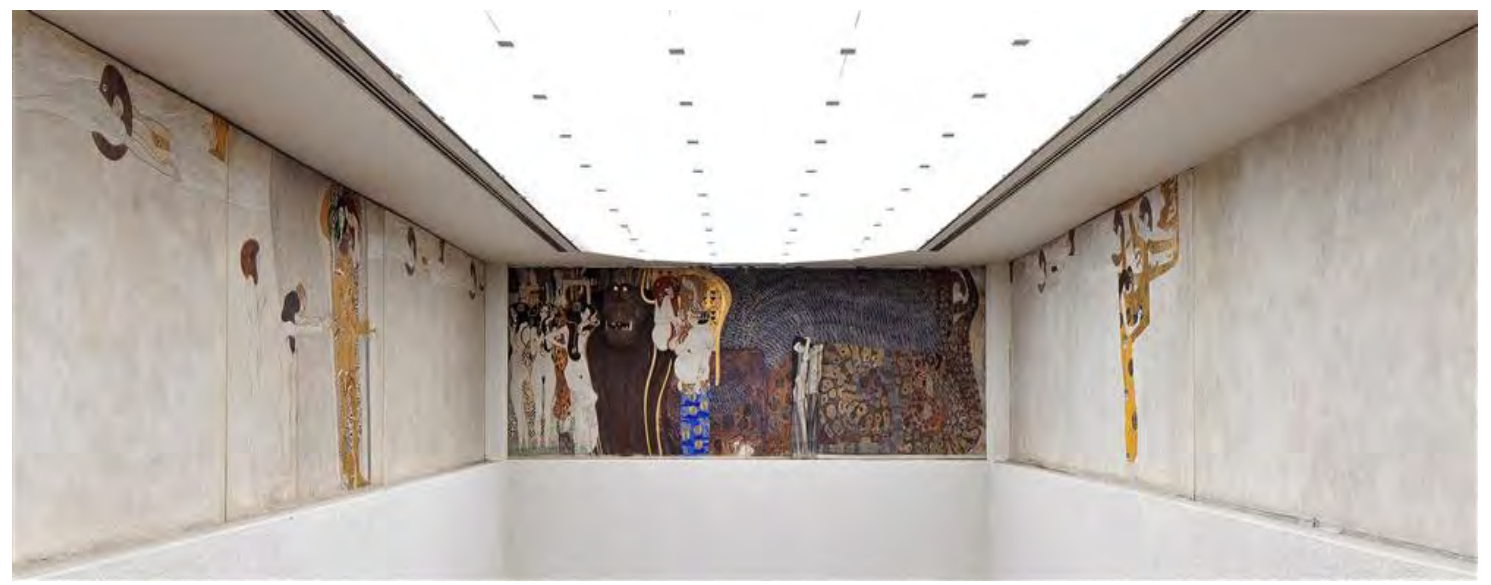

Görsel 1. Beethoven Friz bir tablosu olan Gustav Klimt sergilenen Bölünme Binası/Viyana

(Pivada, 2021).

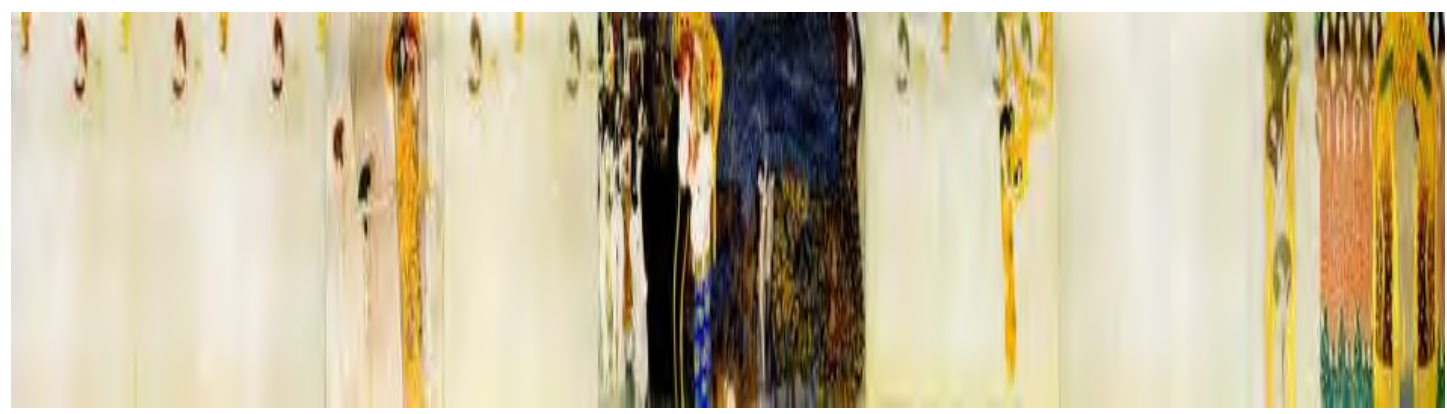

Görsel 2. 9 No'lu Senfoninin dört hareketi (Vergo, 1973).

Klimt, yaratılışının başlangıcında, Beethoven 9 Nolu Sempozyumu metaforik çalışmasında göstermeye çalışmıştır (Vergo, 1973:110). Bence sol kısım birinci harekete, orta kısım ikinci harekete, birinci kısım sağa, üçüncü kısım üçüncü harekete, ikinci kısım ise dördüncü harekete karşılık gelmektedir. İlk hafif müzikten yavaş yavaş ortaya çıkışının doruk noktasına ve nihayet nezaketine kadar, ilk hareketin düzeni, sanat eserinin ilk bölümünün olay örgüsü ile de tutarlıdır. Yoğun müzik havası, yapıtın ikinci bölümünde "Düşman Kuvvetler" temasıyla da örtüşüyor. Üçüncü hareket bir bütün olarak güçlüydü, ancak ikinci harekete kıyasla yavaşladı. Son hareketin ilk yarısı sakinleştiricidir. Sonunda, tüm şarkı doruk noktasına, yani tanıdık koroya gitmektedir. Re minör Senfoni No. 9, Alman besteci Beethoven'in 1822 ile 1824 arasında bestelediği son tam senfonidir. İlk hareket biraz daha yavaş bir Allegro 'dur, sıkı ve soğuk bir atmosferde müzik başlamaktadır. Havanın gerilimle dolu tehlikeli atmosferi, orkestranın fırtına öncesi yağmur damlaları gibi parıldayan vuruşu ve ardından tını davulu ortaya çıana kadar gitgide daha yoğun bir şekilde sessizliği bozan ilk gök gürültüsünün bastırılması ve krizin nihayet birikmesi gibi eklenemez ve çatışma nihayet patlak verir, fırtına sonunda biter. 
Sol duvarı görmek için geri dönelim, müziğin genel havasının ilk bölümün temasıyla ortak bir yönü olduğunu görürüz. Bu bölüm, mutluluk için can atan zayıf insanlığın acılarıyla başlar. Zayıf insanlık, güçlü Şövalyeyi dışlanmış olarak iyi donanımlı, şefkat ve hırs olarak içsel, itici güçler olarak birinciyi mutluluk mücadelesini üstlenmeye sevk eden güçlü Şövalyeye yakışmıştır.

Altın zırhlı kahraman, ağırbaşlı ve kararlı bir görünümle bir kılıca yaslanmıştır. O, güçlü, iyi donanımlı yabancı, arkasındaki bilgelik tanrıçası Athena ve sevgi ve güzellik tanrısı Avatar, insanların vedalaşması ve kutsamalarındaki karşı önlemleri tartışmak için bir araya gelmiştir (Görsel 3).

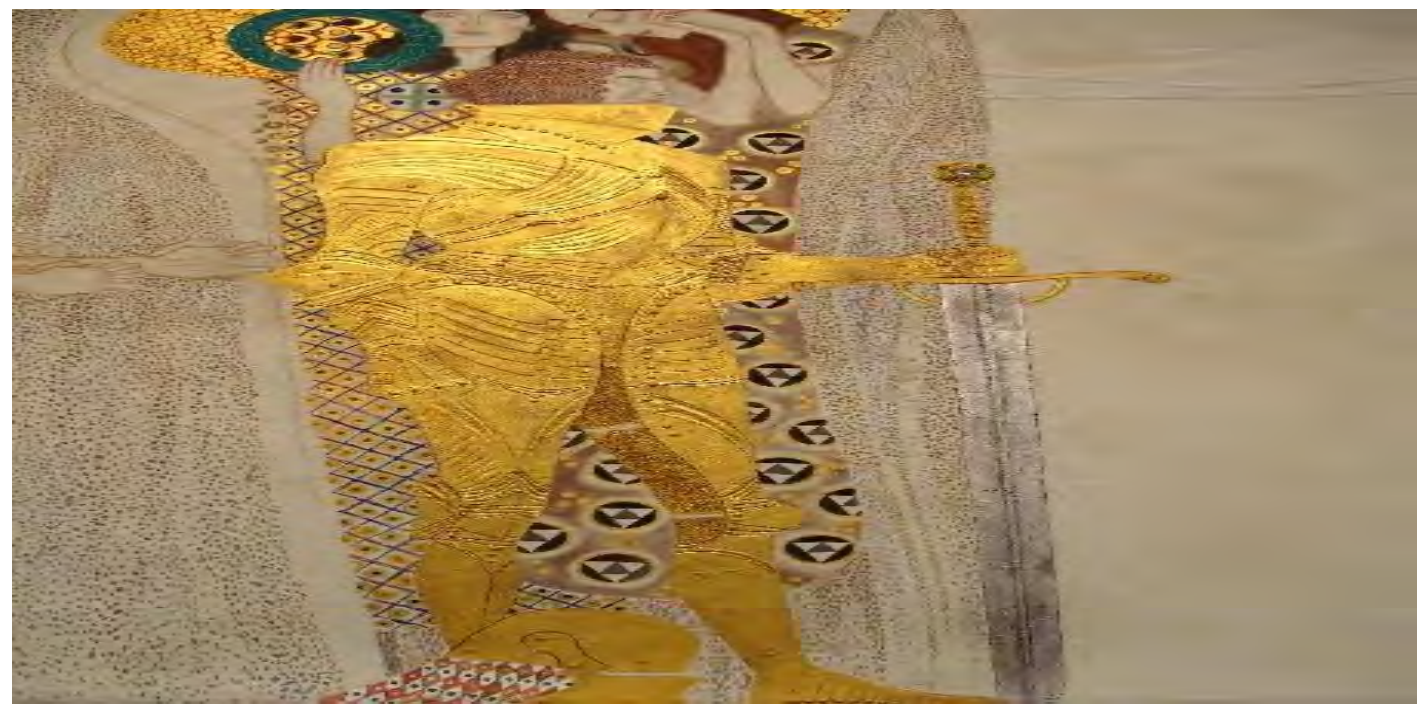

Görsel 3. Knight, Athena ve Avatar (Vergo, 1973).

Resmin boş kısmının üzerinde yüzen melekler, parlak cennete ulaştıklarında durmadan peşlerine düşmeye devam ediyorlar. Gözlerini kapatanlar uyanmış gibi görünür ve bu sürekli güç aynı zamanda insanların mutluluk ve sevgi arama kararlılığının da bir sembolüdür (Görsel 4).

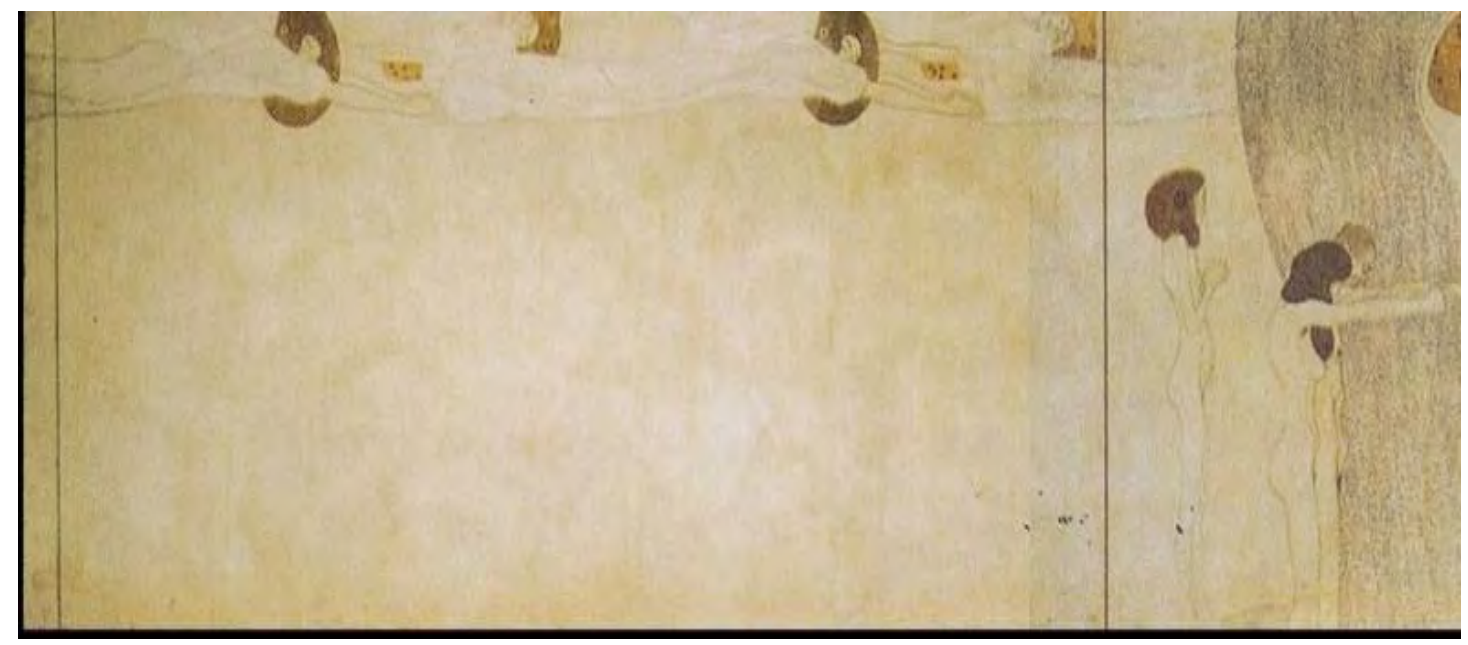

Görsel 4. Melekler (Vergo, 1973).

İkinci harekette ise trompet ve davullarla ordu düşmana doğru ilerliyor. Yüksek ve alçak seslerle değişen orkestra müziği, cesurca düşmanı öldüren savaşçıların sahnesi ve savaşmanın tehlikesi 
canlı bir şekilde gösteriliyor. Burada kullanılan üç tonun ortasındaki ana ezginin halk dansları unsurlarını benimsediği, savaşın trajik sahnesinin daha kolay ve neşeli göründüğü söylenir (Görsel 5-5.1) (Vergo, 1973:110).

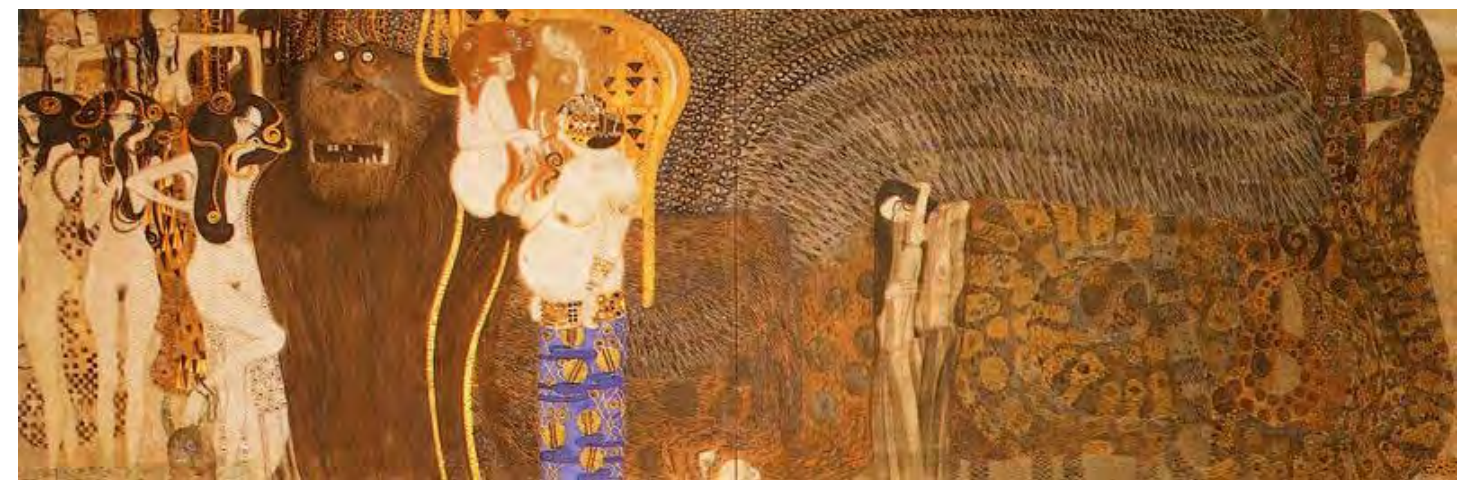

Görsel 5: Merkezi uç duvar: Düşman Kuvvetler, Avusturya galerisi Viyana (Vergo, 1973).

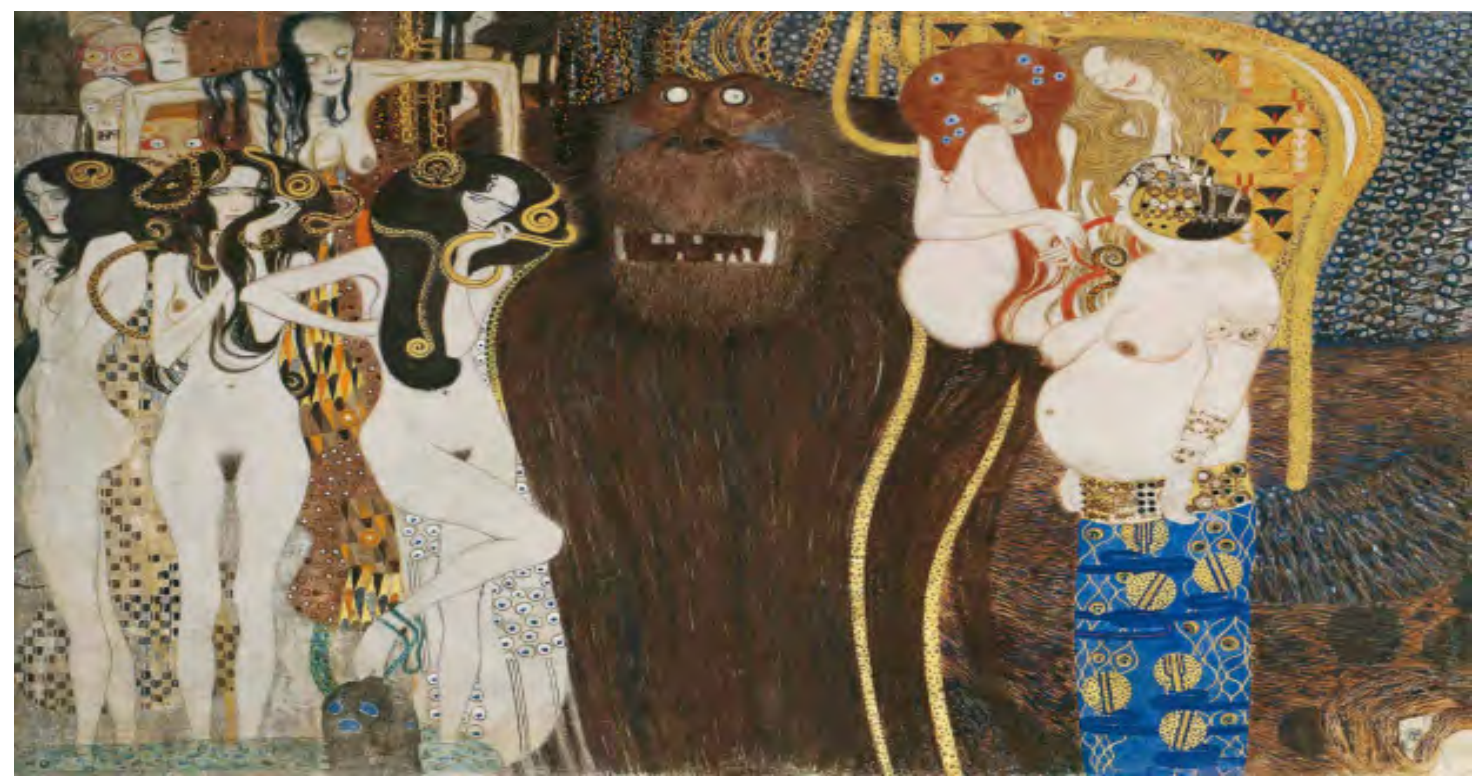

Görsel 5.1: Gustav Klimt, Beethoven Frizi, 1902 (detay), Ayrılık Binası, Viyana, Avusturya (Stanska, 2017).

Üçüncü bölüm ise Adagio, melodik şarkıdır önceki iki hareketle karşılaştırıldığında çok sessiz ve sakin görünüyor. Resimde bulunan goril bir hayvan değil mitolojik bir dev olan Typhon.Tanrıların savaşmaktan korktuğu şeytani güce sahip canavardır. Typhon'un sağındaki Yunan mitolojisi, Typhon'un yılan tüylü dişi canavarlar olarak bilinen ve erkekleri bakışlarıyla taşa çeviren üç kızını tasvir eder. Üç çıplak kadın figürü farklı duruşlarıyla öne çıkıyor. Aşırılık, şehvet ve ahlaksızlığı ifade ediyor. Aşırılık, büyük göbekli bir kadın olarak tasvir edilmiştir. Figür profilden gösterilmiştir ve vücudun üst kısmı çıplak olarak tasvir edilmiştir. Şiddetli bir savaştan sonra, savaşçılar iç gözlem aşamasına girmişler ve cennetin krallı̆̆ çoktan yaklaşmıştır. Hala gözleri kapalı yüzen melekler, cennetten şarkı söyleyen rüyalar aramak gibidir (Vergo, 1973:110). Bu anda, sanat tanrıçası Muse ortaya çıkıyor ve Beethoven Senfonisi No. 9, son doruk bölümünü başlatıyor. Muse, elindeki kitaba bakar ve meleklere Ode to Joy'u söylemeleri için rehberlik etmeye başlar (Şekil 6- 6.1). 


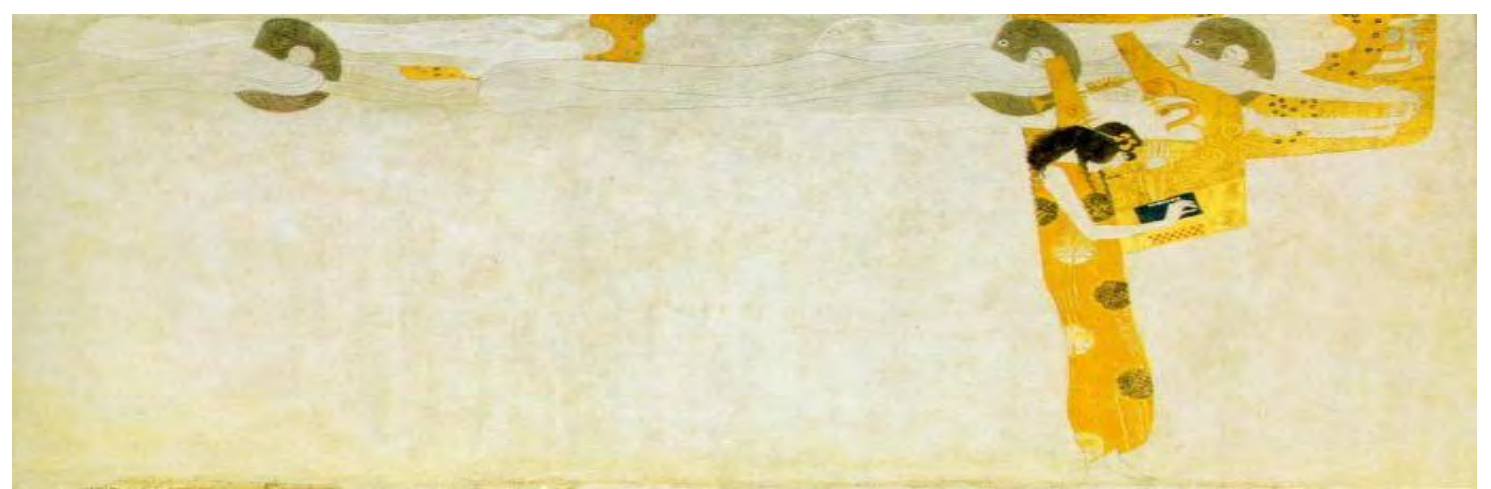

Görsel 6: Sağ Yan Duvar: Mutluluk Özlemi Şiirde Doyum Bulur.

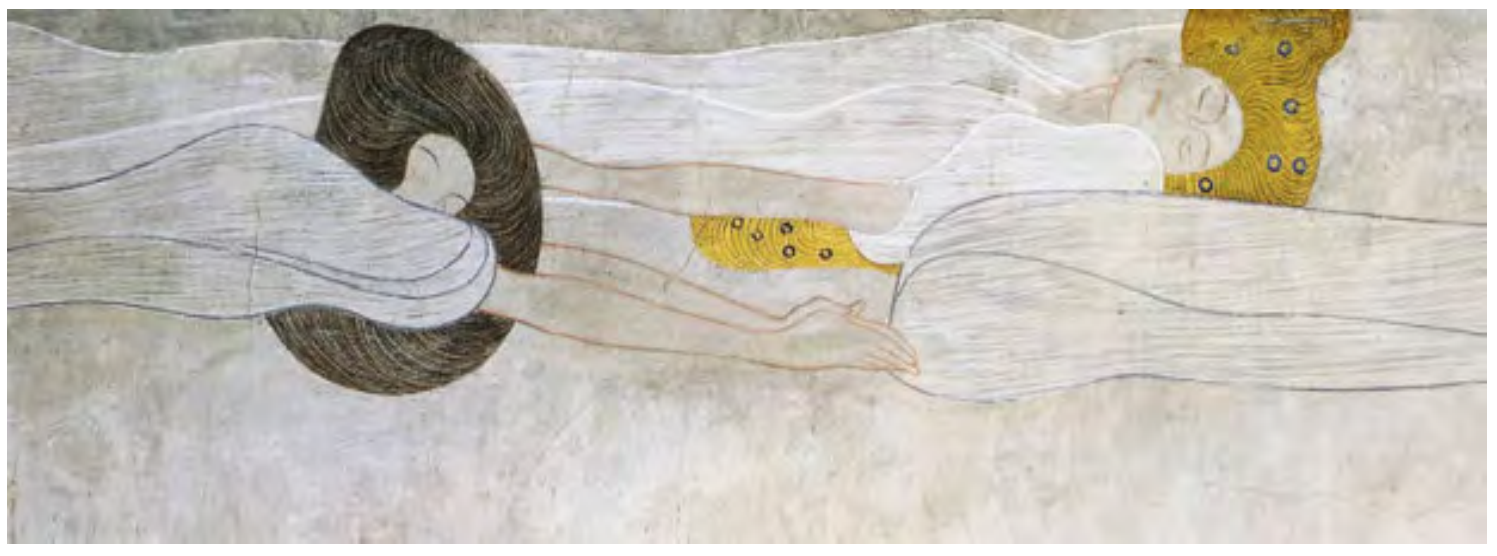

Görsel 6.1: Gustav Klimt, Beethoven Frizi, 1902 (detay): Poesie, Ayrılık Binası, Viyana, Avusturya

(Stanska, 2017).

Dizi ve vokallerden oluşan dördüncü bölüm, tüm işin doruk noktasına ulaşıyor. Vokal kısmı ortaya çıkmadan önce, müzik, sanki ilk üç hareketin bir anısı ve askerlerin iniş ve çıkışlarının bir özetir ve özeti gibi, uzun bir müzik enstrümanı performansından geçmiştir. Woodward, yağmurdan sonra kara buluta nüfuz eden ilk güneş gibi yavaşça "Mutluluk arzusu şiir ve sevgide doyumu bulur" temasını ortaya çıkarır (Vergo, 1973:110). Şarkının vokal kısmı Alman şair Schiller'in ayn zamanda Beethoven'in sevilen şiiri olan Ode to Joy şiiridir, şiiri son hareketin sonu olarak kullanmıştır, Klimt'in Beethoven Frizi de burada sona ermiştir. Parlak bir şekilde gerilmiş. Kutsal ve güzel bir cennette, samimi ve uyumlu bir atmosferde insanlar tüm anlaşmazlıkları ortadan kaldırdılar. Çiftin etrafında çiçekler var. Üzerinde ay ve güneş figürleri var. Arkadan boyanmış çıplak ve kaslı erkek figürü kadın tarafından sıkıca kavranmıştır. Erkeğin öptüğü kadın figürü tam olarak görülememiştir. İyi silahlanmış güçlü şövalye, iç ve dış baskıların motivasyonuyla tüm kötülüklere karşı savaşmıştır (Fırıncı ve Zencirci 2006:137). Bu son sahnede sanat ve şiirin desteğiyle mutlu sona ulaşılmış ve bu tüm dünyaya bir öpücükle bildirilmiştir (Görsel 7). Böylelikle, friz psikolojik insan özlemini, nihayetinde bireysel ve toplumsal arayış ve sanatın güzelliği ile sevgi ve arkadaşlıkla birleşerek tatmin olduğunu açılar (Stanska, 2017). 


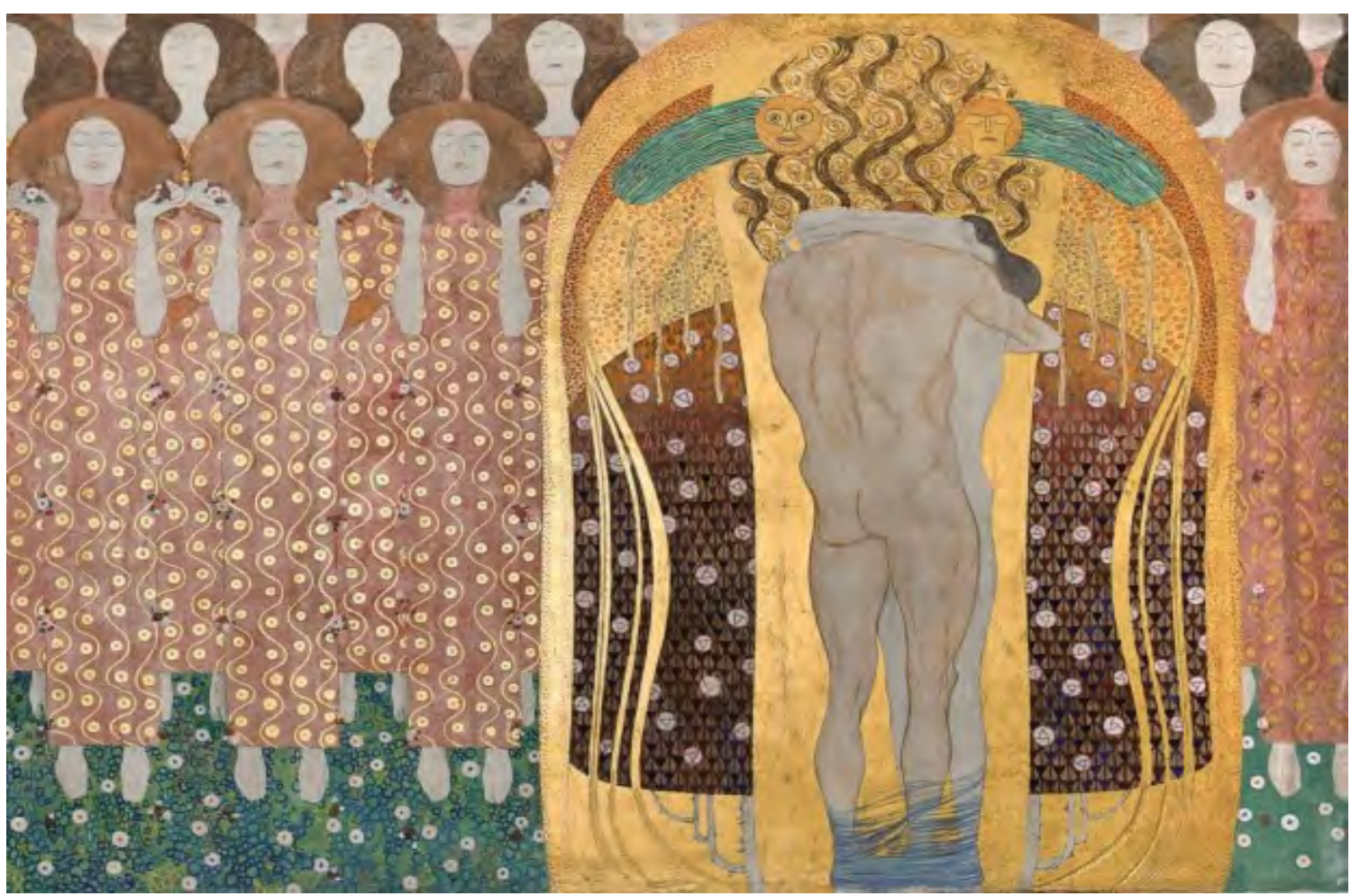

Görsel 7: Gustav Klimt, Beethoven Frizi, 1902 (detay), Ayrılık Binası, Viyana, Avusturya (Stanska, 2017).

\section{SONUÇ}

Gesamtkunstwerk kavramının etimolojik kökeni ve anlam açılımları yanında geçmişten günümüze sanat ve mimarlık camiasında nasıl değerlendirildiği özetlenmeye çalışılırsa; kavramın bir sanat kuramı olarak ele alındığı ve mimarlık disiplinine rahatlıkla entegre edildiği, sanat yapıtlarında ve mimari yapılarda Gesamtkunstwerk olarak adlandırılabilecek tasarlama eğilimleri gözlendiği söylenebilir. Özetle tüm sanat dallarında aranan estetik nitelik, bir kodlama çerçevesi olarak kavramların belirsiz hatlarını daha belirgin kılar. Estetik ve Gesamtkunstwerk kavramları, çeşitli anlam değişimleri ve kaymalarına uğrayarak alanları genişletilmiş veya daraltılmış olarak karşımıza çıkar. Bu nedenle sanat dallarında, yorumlayıcılarına bağlı olarak farklı tavırların, modellerin ve etkilerin bir araya geldiği gözlenebilir.

Sonuçta bu çalışmada, bütüncül bir tasarım anlayışının veya bütüncül bir üslup arayışının resim sanatı dünyasında nasıl var olacağı, olamayacağ üzerine bir yorum denemesi yapılmıştır. Estetik beğenilerin ve doğruların sürekli tartışıldığı ve altının oyulduğu akışkan bir dünyada resim sanatının ortamı da bugünün Gesamtkunstwerk 'inin ne olması gerektiği arayışında olmayacaktır. Çünkü eseri ortaya koyan yaratıcı sadece bilmemizi istediği anlamı bizlere sunar. $\mathrm{Bu}$ nedenle ancak sanatçının kendini ifade ettiği kadarıyla bir Gesamtkunstwerk mümkündür denebilir.

\section{KAYNAKLAR}

Altuğ, E., (2011). Bütünlüğ̈̈n Peşindeki İmzaların İzinde, Sanat Dünyamı (Bütünsel Yapıt: Gesamtkunstwerk), YKY, 121: 68-78. 
De Bolla, P. (2006). Sanat ve Estetik, Kubilay Koş (çev), İstanbul: Sanat ve Kuram Dizisi, Ayrıntı Yayınları.

Doğan, M. H. (1975). 100 Soruda Estetik. İstanbul: Gerçek Yayınevi.

Fırınc1, M. ve Zencirci, D. E. (2006). Gustav Klimt ve "Beethoven Friz", Dokuz Eylül Üniversitesi Buca Eğitim Fakültesi Dergisi, 20: 137-144.

Frampton, K. (2007). Modern Architecture: A Critical History. London: Thames \& Hudson Ltd.

Fubini, E. (2006). Müzikte Estetik, Furat Genç (çev), Ankara: Dost Kitabevi.

Galard, J. (2011). "Yapıtsız Sanat", Elif Gökteke (çev), Sanat Dünyamız (Bütünsel Yapıt: Gesamtkunstwerk), İstanbul: YKY, 121: 26-32.

Hançerlioğlu, O. (2008). "Estetik" maddesi, Felsefe Sözlüğü, İstanbul: Remzi Kitabevi, 93-94.

Haydaroğlu, M. (2011). "Bütünsel Yapıt: Gesamtkunstwerk", Editörden, Sanat Dünyamız İstanbul: YKY, 121: 3.

Masiero, R. (2006). Mimaride Estetik, Ankara: Dost Kitapevi Yayınları. S:170-175

Millington, B. (1992). The Wagner Compendium: A Guide to Wagner's Life and Music. London: Thames \& Hudson.

Most, G. W. (2011). "Nietzsche, Wagner ve Bütünsel Sanat Yapıtına Duyulan Özlem", Elif Gökteke (çev). Sanat Dünyamız (Bütünsel Yapıt: Gesamtkunstwerk), İstanbul: YKY, 121: 4-11.

Önen, Y. ve Cemil Z. Ş. (1993). Almanca-Türkçe Sözlük 1, Cilt: 1 (A-N), Ankara: Türk Dil Kurumu. Sedlmayr, H. (1998). Verlust der Mitte, Salzburg: Müler (Otto).

Sönmez, N. (2011). "Gesamtkunstwerk ve Çağdaş Türk Sanatı Üzerine Notlar", Sanat Dünyamız (Bütünsel Yapıt: Gesamtkunstwerk), İstanbul: YKY, 121: 20-25.

Sözen, M. ve Uğur T. (1986). Sanat Kavram ve Terimleri Sözlüğ̈̈̈, İstanbul: Remzi Kitapevi.

Tanju, B. (2010). Mimarlık Düşüncesi Tarihi. Basılmamış Lisansüstü Ders notları, 2010- 2011 Bahar Yarıyılı, Yıldız Teknik Üniversitesi, İstanbul.

Vergo, P. (1973). Gustav Klimt's Beethoven Frieze. The Burlington Magazine(115), 108-113. The Burlington Magazine: https://www.burlington.org.uk/archive/search-archive/search/result adresinden 11 Mayıs 2021 tarihinde alınd.

Wagner, R. and Ashton, W. E. (1993). The Art-Work of Me Fumre and Other Works (trans.), Lincoln and London: University of Nebraska Press.

Williams, R. (2007). "Aesthetic", Anahtar Sözcükler, İstanbul: İletişim Yayınları, 3941.

Woods, Lebbeus, 7 Eylül $2010 . \quad$ "Gesamtkunstwerk", https://lebbeuswoods.wordpress.com/2010/09/07/gesamtkunstwerk-2/ (Erişim Tarihi: 26.5.2021).

QR Code: DecimusAquila. (2008). Ludwig Van Beethoven's Ninth Symphony. Nisan 2021 tarihinde Youtube: https://www.youtube.com/watch?v=_-mvutiDRvQ\&ab_channel=DecimusAquila adresinden 26 Nisan 2021tarihinde alındı. 


\section{GÖRSEL KAYNAKLAR}

Görsel 1: (2021). Beethoven Frizi-Gustav Klimt. https://www.pivada.com/en/gustav-klimt-thebeethoven-frieze adresinden 26 Nisan 2021 tarihinde alındı.

Görsel 2: Vergo, P. (1973, 02). Gustav Klimt's Beethoven Frieze. The Burlington Magazine(115), 108-113. The Burlington Magazine: https://www.burlington.org.uk/archive/searcharchive/search/result adresinden 11 Mayıs 2021tarihinde alındı.

Görsel 3: Vergo, P. (1973, 02). Gustav Klimt's Beethoven Frieze. The Burlington Magazine(115), 108-113. The Burlington Magazine: https://www.burlington.org.uk/archive/searcharchive/search/result adresinden 11 Mayıs 2021tarihinde alındı.

Görsel 4: Vergo, P. (1973, 02). Gustav Klimt's Beethoven Frieze. The Burlington Magazine(115), 108-113. The Burlington Magazine: https://www.burlington.org.uk/archive/searcharchive/search/result adresinden 11 Mayıs 2021tarihinde alındı.

Görsel 5: Vergo, P. (1973, 02). Gustav Klimt's Beethoven Frieze. The Burlington Magazine(115), 108-113. The Burlington Magazine: https://www.burlington.org.uk/archive/searcharchive/search/result adresinden 11 Mayıs 2021tarihinde alındı.

Görsel 5.1:Stanska, Z. (2017, June 26). Painting Human Desire For Happiness - Klimt's Beethoven Frieze. Nisan 2021 tarihinde DailyArt Magazine: https://www.dailyartmagazine.com/humandesire-klimt-beethoven-frieze/ adresinden 26 Nisan 2021 tarihinde alındı.

Görsel6: Vergo, P. (1973, 02). Gustav Klimt's Beethoven Frieze. The Burlington Magazine(115), 108-113. The Burlington Magazine: https://www.burlington.org.uk/archive/searcharchive/search/result adresinden 11 Mayıs 2021tarihinde alındı.

Görsel 6.1: Stanska, Z. (2017, June 26). Painting Human Desire For Happiness - Klimt's Beethoven Frieze. Nisan 2021 tarihinde DailyArt Magazine: https://www.dailyartmagazine.com/humandesire-klimt-beethoven-frieze/ adresinden 26 Nisan 2021 tarihinde alındı.

Görsel 7: Stanska, Z. (2017, June 26). Painting Human Desire For Happiness - Klimt's Beethoven Frieze. Nisan 2021 tarihinde DailyArt Magazine: https://www.dailyartmagazine.com/humandesire-klimt-beethoven-frieze/ adresinden 26 Nisan 2021 tarihinde alındı. 